\title{
Correction to: Secularism Versus Political Islam: The Case of Tunisia
}

\section{CORReCtion to:}

Chapter 6 in: H. Alvi, The Political Economy and Islam of the Middle East, Political Economy of Islam, https://doi.org/10.1007/978-3-030-17050-9_6

In this chapter the flags of Turkey and Tunisia were reversed and the same has been corrected in this revised version.

The updated original online version of this chapter can be found at https://doi.org/10.1007/978-3-030-17050-9_6 